\title{
SECRECY AND SELF-INVENTED IDENTITY IN PHILIP ROTH'S NOVEL THE HUMAN STAIN
}

KABIDEEPA HANDIQUE

Research Scholar, Assam University, Diphu Campus, Assam, India

ABSTRACT
This paper aims at examining the ambiguous nature of identity in Philip Roth's The Human Stain. It is analysed here
how identity of an individual is camouflaged to attain the American Dream. Roth in this novel attempts to bring the plight
of two minority community in America by placing them against each other. These two groups are the Jewish American
and African American. Roth presents the ambiguous shades of identity in the novel by employing the weaponry of secrecy
and self-invention. The desire for a self-invented identity will be analysed with the help of psychological theories and
arguments by Karen Horney and Abraham Maslow.
KEYWORDS: Identity, Secrecy, Self-Invention, Ambiguous \& American Dream

Received: Aug 05, 2019; Accepted: Aug 26, 2019; Published: Oct 22, 2019; Paper Id.: IJELDEC20191

\section{INTRODUCTION}

An individual's negotiation with society at large is to establish the meaning of his or her identity. Identity is a label and both relational and contextual. The meaning of identity varies with reference to various fields of study. Thus Identity can be seen as the distinctive characteristic that channelizes an individual with a larger social category or group. The awareness of one's identity occurs through one's identifications with significant others- parents or groups as they are perceived. In a society an individual derives his or her identity from their roles assigned in the society. Their personal traits and characteristics are reflections of the group they belong and cling to. Psychological identity can be related to one's acknowledgement of self-image, self-esteem, and individuality. The representation and description of "identity" is a central task for psychologist, sociologist and anthropologist. Identity has been the theme of various forms of art. The theorist of identity such as Eric Erikson, Abraham H. Maslow, Karen Horney, Alfred Adler, Sigmund Freud, etc. have defined and channelized different colours and shades of identity from different perspectives in their works.

Identity plays a central role in the novel The Human Stain, with multiple determinations: racial, ethnical, social and national. Here Roth questions the existence of 'Identity' by negotiating with the 'Self' of an individual. The Human Stain unveils the secret of Coleman Brutus Silk, a professor of classics and once dean of faculty at Athena College, who is subjected by the forces of political correctness and hatred. The narrator is Nathan Zuckerman, Roth's alter ego who acts as the spokesperson in the novel. The narrative is, by and large, stimulated by the surprising revelation made to Zuckerman that a grave secret lay at the centre of Coleman's life. While attending the latter's funeral, Zuckerman is made aware that Silk was in fact AfricanAmerican by birth and that his racial origins had been concealed to the world by his determined commitment, made some fifty years earlier, to sneek as a white man. Through Coleman's act of passing as white, Roth aims at depicting the fluid and protean notion of identity in the context of postmodern America. He attempts at 
distorting the fixed notion of the American Dream and creating a character like Coleman to examine the risk that an individual undertakes to achieve that Dream.

\section{STAINED IDENTITY IN THE HUMAN STAIN}

The stain that Philip Roth attempts to depict through the title of the novel The Human Stain is the stain of Coleman's past that has stained his present identity. Coleman Silk maintained secrecy in his self-inventory identity by effacing his past. The whiteness of Silk is as a result of his erasure of his blackness. He attempts to pass in the eyes of others as perfect and stainless. He was born black but chose to pose himself as a white and socially advance in the world around him. He chose to be a Jew, hunted for a white partner so that he reproduces white children and be a part of the bigotry America. He rejected his black family in East Orange and recreated a new Jewish past of his life to narrate to his wife, children, and the people around him. His lies, secrecy, self-invention leaves a stain which bears its fruits when he was at the peak of his career and the medium of his nemesis is quite ironical in the manner of its character assassination of Coleman. It is because lying and self-deceiving hypocrisy are seen as "stains" to one's character. Coleman deconstructs and reinvents his own past as a white but what strikes him is when charged with racism for referring two of his absent student's as "spooks" who turned to be black. By enquiring about the very existence of the missing students Coleman pronounced the word spooks he was referring to their existence in the customary and primary level of the usage of the word. He had no knowledge about the colour of the two students' as they did not attend a single class of Coleman's paper. He resigned from the job under the racist cloud as he didn't had any alternative; he couldn't reveal his lifelong secret to save his job.

Coleman chose to be white, a Jew by rejecting his birth right as a black and towards the end of his life suffered the pangs and wrath of a community that he rejected and disowned. The stain of his past stained his self- invented Jewish identity and there was no escape from this accusation. He could do nothing but suffer for the wrongs done to a race, ethnic class. The colour that he chose to mask himself ruined his well-constructed reputation because sometimes "the strongest defences are riddled with weakness, and so in slips" Coleman spoke the word that disgraced his career. (The Human Stain42) He realised that his dark colour stains his identity and in a society as an African American it shall hinder his progress but his choice of being a Jewish American, another minority group in America rather stained his identity.

By placing two major minority communities of America and pitting them against each other and shifting their identities Roth attempts at showing that no matter black or white, the other will always be a victim at the hands of the bigotry in America. Being white Coleman was charged with racism because he was a Jew and the college authority believed in the charge because this "is what Jews do."

(The Human Stain9)

Roth brings both the Jewish community and African American on the same arena of struggle and prejudice in contrast to the whites of America. As Coleman speaks out in indignation about the whites, it is also Roth speaking out his frustration about the Jewish stereotype in America. Philip Roth as a Jewish American is well aware about the treatment meted out against the Jews in America. It is a series of psychological trauma that each Jew carries with them in connection with their association with the atrocities of Holocaust, Anti-Semitism and so on. The non-hyphenated Americans are not bothered about the stories of suffering of the Jews neither they are interested in their rise of social status. Coleman suffered because of choosing to be a Jew and when a Jew is in any problem people believe as Zuckerman opens up, "simply to make the accusation is to prove it. To hear the allegation is to believe it. Only a label is required. The label is the motive, 
evidence, logic. Why did Coleman Silk do this? Because he is an $x$, because he is a $y$, because he is both." (The Human Stain 290) This line expresses Roth's anxiety and sympathy for all that Coleman Silk had unfairly endured as a Jew.

\section{DESIRE FOR SECRECY AND SELF-INVENTED IDENTITY}

Coleman's cycle of self-invention through secrecy is deeply engraved with his desire and choice to get fully integrated into society. Amy Hungerford in her series of Lectures in Yale University titled "The American Novel since 1945", defines desire as that "permanent looking towards the other thing, the thing that you are not, the thing that you do not have, the thing that is absent from you". He desired to be the Jew who could somehow manage to pass off as a white in America as being a Jew in America was not subjected to so much doubt and uncertainty as compared to an African American. Hence Coleman had the utmost desire to be a white and have access to all that he is denied being Black. As Coleman did not have the whiteness of a white and the attributes that comes with it, the desire to have that thing became unstoppable in him. Coleman's desire to undo his fate and rise towards personal aggrandizement is reflected in the novel. He was so obsessed with the whiteness of the whites in America that he made it his desire and passion to not let it slip from his fate. He knew he had the weaponry of whiteness with which to pass off not completely as an American but to some extent as a Jewish American and fulfil his American Dream.

Abraham Maslow defined eight ways to self-actualization in his book "Toward a Psychology of Being." Some of the clinically observed characteristics of an individual towards self-idealization/self-actualization as described by Maslow are:

- $\quad$ Superior perception of reality.

- Increased acceptance of self.

- Increased detachment and desire for privacy.

- A real self; a firm identity; autonomy, uniqueness.

He says that all the basic needs of an individual are not deficits but those needs where frustrations are pathogenic tend to be deficits. For him, the individual can lead towards self-actualization only when he actively makes conscious and positive choices. He further adds that when confronted with an opportunity, the self-actualizer will risk safety to encounter new and challenging experiences. In The Human Stain Coleman Silk, a mullato risks to perform a lifelong secrecy and concealment as a Jew, ensnared by the stranglehold of history that is one's own time. His act of masquerade is carried out with the hope of exploring the more private self and unexplored territory of the private self that lies beyond his assigned social role as an African American.

As an African American Coleman had been a victim of racial prejudice. His blood was rejected by his friend's family, who had met with an accident because he was coloured. They "thanked him and told him that they had enough but, he knew what the real reason was." (The Human Stain105) It wasn't that he did not know what was going on, as Zuckerman says, "He was too smart not to know. He saw, he heard- he over-heard Coleman knew what was occurring in his life. He also knew what wasn't occurring in his life, what was missing at the center of his life anyway. This indifference of behaviour depicted by Coleman can be analysed through Maslow's perspective on an individual. As Maslow sums up, human beings often resent being criticized which is a sign of denying their individuality that is self and identity. They react to criticism by reaffirming their identity through different channels available to them. He was refused an entry at Norfolk 
whorehouse for being black, and at Washington he for the first time called a nigger. The word nigger, instigated and provoked him to further his act of masquerade. The determination for passing lifelong as a white in secrecy came to Coleman "when he was called a nigger to his face at Washington D.C. He finally realized the enormous barrier against the great American Dream that his father had been for him by being black.

Secrecy is at the very centre of what identity signifies in this novel. Coleman had devised his whiteness to invent and claim impregnability in a grandiose way. Zuckerman praises Coleman's secrecy as, he has not encountered or come to terms with such a secret with so much of planning and execution in a grand style. In the words of Zuckerman, Coleman's secrecy was his singular act of invention for which he toiled every day and night to be what he had finally made of himself. The search for identity in humans is a natural phenomenon which is connected with the psychological and social needs of an individual.

As Maslow describes the psychology of human being:

Every human being has two sets of forces within him. One set clings to safety and defensiveness out of fear. The other set of forces impels him forward toward wholeness of Self and uniqueness of Self, toward full functioning of all his capacities, toward confidence in the face of the external world at the same time that he can accept his deepest, real, unconscious Self.

(Maslow 45)

Coleman was determinant in playing with his colour after his father's death who tolerated all the prejudice as a black while serving at the railway dining car without any protest. He knew the power of his secret and the pleasure that was to be accomplished from executing the power in a proper manner. He chose to experience the pleasure that his power brings in being the opposite. Coleman knew well that in this process towards selfrealization he had no one to counter or even his parents or race. He was free to play his game of secrecy and selfinvention on the scale that he desired. As he grew he saw his father and brother "had been condemned to accept the insults, but he wasn't. He decided not to."

(The Human Stain105)

Self- realization as postulated by Karen Horney in her book Neurosis and Human Growth, always entails selfglorification:

"Each person builds up his personal idealized image from the materials of his own special experiences, and also his given faculties. The individual may come to identify himself with his idealized, integrated image. And this idealized self becomes more real appealing because it answers all his stringent needs. Self- idealization is a solution that implicitly promises to satisfy all the inner needs that have arisen in an individual at a given time"

(Horney23)

Roth's protagonist Coleman saw his colour as the means to be free from all those that binds him as an African American. The humiliations that he encountered at Howard reinforced his decision to pass as white. He is determined to be a free agent and to define himself, not be defined by others. At Howard he was a negro but with or without Doc Chizner, he was without thinking about it. He was Coleman, the harbinger of his race towards achieving whiteness. From here begins Coleman's quest for freedom to satisfy all his inner needs and his declaration for freedom from his 
blackness is praised by the narrator. Coleman announces his journey towards secrecy as, one cannot let the powerful impose its power on the powerless as power is something that keeps on shifting so with time the less powerful will impose their supremacy on the powerful. Coleman unchains himself from the barriers of a society that hinders his progress on the basis of his colour. By passing as white he controls his own fate and destiny. He is reborn as a Jewish American and free to be whatever he aspires to be, free to accomplish the zenith. He attains the confidence to be his particular "I" that is Coleman himself.

The building up of Coleman's personal idealized self- image as Horney theorizes, Coleman unchained himself not only from his father's identification but from all the rebuke and criticism that his father had ever had to go through as an African American. He was free on a platform unimaginable or beyond the reach of his father. By being white he was now as free as his father was unfree being black. He was free from those impositions, humiliations, the obstructions directed towards him on account of his racial identity. He was now independent to explore the limitless, self-defining meanings of the pronouns we, they, and I. He was able to enact his skin colour the way he desired, and colour himself exactly the manner he aspired to.

As postulated by Horney when an individual proceeds towards freedom he frees himself "to love and to feel concern for other people. At any rate, whether for ourselves or for others the ideal is the liberation and cultivation of the forces which lead to self-realization." (Horney16) Roth's protagonist in a similar set of determination decided to tell the world that his mother was dead, for the notion of freedom that he desired for himself. To be free and on one's own decided accord there are certain tests to be conducted and verbally murdering her was one. It was only option available for him to be the man he has opted to be, unalterably disconnected from what he was, at the moment of his birth. The turn towards freedom as forwarded by Horney makes the individual "meaningful to himself gradually and unconsciously the imagination sets to work and creates in his mind an idealized image of himself he becomes a hero, a genius, a supreme lover, a saint, a god." (Horney 22) Coleman was confident of his secret for reasons like his academic prowess, color, and the biblical mark. Through his act of secrecy the narrative attempts to unravel the fact that he was successful in his secrecy because it was solely his invention. He loved secrets and the secret of nobody's knowing what was going on in one's head, fascinated and channelized the secret mission of Coleman. He experienced a sense of great relief and imagined himself to be a superior being. The circumstance under which Coleman masters the trick of concealment is portrayed by the narrative in a manner akin to Horney's visualization of an individual towards freedom. Coleman's state of mind was in a phase where everything he saw made him feel a sense of love and admiration not only for himself but for all that was visible and within his reach. He attained a state of mind where he believed that as if everything in nature were a recreation of his own life- the sun, the sky, the mountains, the river, the trees, just Coleman Brutus "Silky" Silk carried to the millionth degreenobody knew his secret. It was all because his secret was entirely his. He owned it and could articulate it the manner he aspired.

Another important factor that contributed towards Coleman's successful journey of masquerade was the biblical mark of circumcision that was a proof of his being Jewish. He bore that mark owing to his mother's profession as a nurse. The hospital was staffed with Jewish doctors and being with the Jews his mother was convinced of the hygienic benefits of circumcision, and so the Silks circumcised their son as the Jews did. And that was the beginning of his journey towards self-definition and which was possible as an outcome of the Silks broader outlook beyond the bounds of race. With the biblical mark he was an unknown amalgamation of the Jews and the African American in America. 


\section{POSTMODERN IDENTITY IN THE HUMAN STAIN}

Identity as postulated in postmodern context is not fixed but fluid and protean. It does not have one core or permanent self. This self and identity is in continual progress, as the boundaries between them and others are negotiated. As Karen Horney puts it, "The individual alienated from himself needs a 'substitute' for his real self- something that will give him a stronghold, a sense of identity." (Horney21) Coleman's alienated self too needed a "substitute" that would provide him a base, a feeling of identity and he found that in his skin colour, his new identity as a Jewish American. The search for accomplishment, according to Horney, is an ambition, toward external success and excelling itself. Coleman's ambition was, "the passionate battle for precious singularity, his battle against the Negro fate" (The Human Stain183) He had the passion for singularity, self-discovery and so he adapted with his newly invented identity because of his academic prowess and his light colour.

According to Horney, "In a competitive culture, everybody wants to get ahead of the next fellow, and be better than he is, it is obvious that the ambitious person will have his grandiose image of himself "(Horney 26-28) It is quite clear that being an African American Coleman wanted to overcome the limits that his race provided in America. Even Zuckerman supports Coleman in this regard because his aim was to be two acquire a newly invented identity instead of the old one. Coleman's dream was to be free as an individual and so he chose to be in cognito or in disguise. He had chosen for himself an identity to accomplish what his race had earlier restricted. He decided to be neither Black nor White but something in between that is to be a Jewish American wherein by being Jewish he shall have access to those aspects of life which were denied to him as a black. This is why neither Zuckerman nor Roth sees Coleman's act of concealment as treacherous but simply as an act of survival strategy. He was now a trickster performing his act well, after two failed relationship he married Iris Gittleman, a Jewish woman. Zuckerman justifies Coleman's act of risking marrying a Jewish woman as it gave him back the opportunity to live his life on the scale that he imagined. She was the medium through which he could make himself anew and so he decided to marry Iris in order to achieve his goal. Being with Iris will put an end to all speculations regarding his color and so he was determined to do so. The act of marrying Iris was the solution to keep his secret a lifelong secret. He was at the peak of his secret and with Iris, he's back in the ring, "he has the secret again. And the gift to be secretive again" (The Human Stain135-36) Thus Coleman created his own fate and identity unilaterally on his own by deciding to pass as white.

\section{CONCLUSIONS}

By depicting Coleman's plight in the guise of a Jew Roth's primary concern seems to portray the status of Jew's in America. The act of switching or choosing identities in a postmodern world as presented in the novel is indicative of Roth's attempt to depict that in our contemporary society, our private and public identity is intertwined and our social existence is always determined by our racial category. The act of passing in the novel is a grim way of being defined by our social conditions. Coleman claims an identity which he has not inherited because the choice was easily available to him. Through this act of passing Roth also brings to the forefront the flaws in the American Cultural experience which according to Roth is fragmented and sectionalized in terms of race.

Finally, Roth by attributing secrecy to his protagonist is his defiant decision to see him as an unknown, uncohesive individual in the postmodern America. It is for the readers to decipher the enveloped identity and see it as a struggle of an individual defining himself beyond the social determinants of a nation as real. Thus by depicting his protagonist as a product of the postmodern era, who had been closing the door to a past, to people, to a whole race Roth 
aims at unravelling the notion of identity in the postmodern era as fluid and protean. His protagonist simply aspired to be recognized as an individual whose goal was the achievement of the American Dream and the path he chose is not to be seen as deceptive but simply as a means towards success. Roth's fiction is itself an answer to such a question, because it is America and the possibilities and hopes that it provides to its people, anyone could have done it the way Coleman did, if hindered.

\section{REFERENCES}

1. Erikson, Erik H. Dimensions of a New Identity. Norton and Company Ltd. 1974.

2. Erikson, Erik H. Identity and the Life Cycle. Norton and Company Ltd. 1980.

3. Horney, Karen. Neurosis and Human Growth. Norton and Company Ltd. 1991.

4. Maslow, Abraham H. Toward a Psychology of Being. Wilder Publications. 2011.

5. Maslow, Abraham H. Religions, Values, and Peak-Experiences. Penguin Books. 1975.

6. Roth, Philip. The Human Stain. 2000. Vintage Books. 2001.

7. Neelima, C. (2014). The Place of Nostalgia in Diaspora Writing: Home and Belonging in The Fiction of Bharati Mukherjee. International Journal of English and Literature (IJEL), 4, 33-40.

8. Singh, R. K. (2012). Humour, irony and satire in literature. International Journal of English and Literature, 3(4), 63-72.

9. Rubin-Dorksy, Jeffrey. "Philip Roth and American Jewish Identity: The Question of Authenticity”, in Harold Bloom, ed. Philip Roth. Chelsea House Publishers. 2003: 205-232.

10. Bhattacharjee, S. 'Blue Velvet'(1986) A Dark Trip Down the Slippery Isles of Voyeurism and Human Sexuality.

11. Wirth-Nesher, Hana and Michael P. Kramer. The Cambridge Companion to Jewish American Literature. Cambridge University Press. 2003. Print

12. Wisse, Ruth R. The Modern Jewish Canon: A Journey Through Language and Culture. The Free Press, 2000.

13. Cheema, R. J., \& Bhangu, J. P. K. Witches or Warriors-an Analysis of Toni Morrison's Sula and Song of Solomon.

\section{AUTHOR PROFILE}

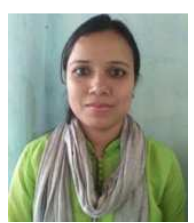

Kabieepa Handique has completed my Masters from Tezpur University, Assam, and M.PHIL IN Assam University, Diphu Campus on Jewish American Identity, anti-Semitism, Holocaust, and the prejudices against Jews in general. She was currently pursuing my Ph.D on Indian Jewish writing and their issues of identity crisis, alienation and ambivalence in the works of Esther David and Jael Silliman. Her research work encompasses two Indian Jewish communities- Bene Israel and Baghdadi Jews. It is a work about the experience of being Jewish in India and a Jew in connection with the world jewry. 
